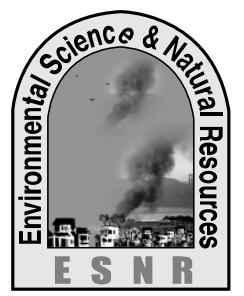

J. Environ. Sci. \& Natural Resources, 7(1):197-206, 2014

ISSN 1999-7361

\title{
Demographic Approach to the Empirical Study of Maternal and Child Health Profile and Policy in Bangladesh
}

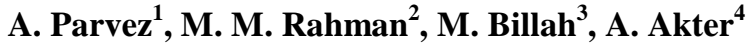 \\ ${ }^{1}$ Department of Environmental Science, ${ }^{3}$ Faculty of Disaster Management, ${ }^{4}$ Department of \\ Emergency Management \\ Patuakhali Science and Technology University, Patuakhali, Bangladesh \\ ${ }^{2}$ Department of Political Science, Faculty of Social Science, University of Dhaka
}

\begin{abstract}
Health and wellbeing of women and children especially on maternal and neonatal health has long been a common goal throughout the world. Understanding the status of maternal and child health care for our country can provide us the valuable information regarding the impact of enriching health policies. Various types of annual reports, journals and published materials on maternal and child health and its regulatory factors with overall health status were collected and analyzed to finalize these articles. The findings of reviewing article was that on annual basis $75.6 \%$ of the children born in without the supervision of trained health service providers and $38.96 \%$ death occurrence for perinatal asphyxia due to below level neonatal health circumstances. Child mortality rate under 5 years old is 66 per 1000 in rural areas and the slum areas the rate above $90 \%$. The coverage of the vaccine program has also improved (99\%) substantially. The result also showed that sanitation and safe drinking water situation has improved than previous decades. The review report revealed that some of the problems are still remaining in the health sector to achieve the MDG, though we made great strides in improving the health of its population, much more than a country's development situations. Inequities in access to health care, lack of meaningful participation of citizens in the health care system and the absence of effective accountability mechanisms has been found as a main health barriers. Finally, the progress of health care system has worked much, the government should support funding and logistic to continue and promote the enhancement of overall health care system in Bangladesh.
\end{abstract}

Key worlds : Child Health, Population drinking water, sanitation

\section{Introduction:}

Everyone has the inherent and basic right to access adequate health care facilities. The government of the state is responsible to ensure health care for its citizens. Healthy nation cannot be found except an effective health care system and that is why a country needs a good health policy. Such policy will fulfill the demands of the people of the country, while health service providers will be encouraged and inspired. The main objectives of health policy in Bangladesh to ensure that the people have access to health care services through their lifetime, improve the status of their reproductive health, guaranty their right to practice family planning, control the HIV infections rate and to raise the awareness of women health issues. Further it may include the quality of birth, reducing the incidence of the birth defects, improve the safety of maternal delivery, reduce the infant and under five mortalities, improve child hood nutrition and to strength the education of child health care.
Reliable, complete and timely information on maternal and child health are essential for public health decision-making and actions. So the researcher has taken in to account for empirical study of maternal and child health care profile to understand better about the present circumstances by answering the following questions. What are the status of maternal and what factors are working as a regulatory factor? It has some more study on evolution of the policy and present scenario of health including policy making, planning, programming, maintaining and how far we are from the achievement of MDG.

\section{Methodology:}

This paper is based on review of relevant published documents. The data has been collected on multi modal approaches, Peer reviewed journal articles and research reports were selected for reviewing. A number of relevant personnel were also interviewed who 
had been involved with health care organizations. The collected data analyzed to get the statistical value and presented as different form of tables, charts and graphs.

\section{Maternal health:}

The results regarding the maternal health reported that only $24.4 \%$ child born in Bangladesh under the supervision of trained health service providers and its rate is highest in Meherpur district about $61 \%$ and lowest in Bandarbon about 8\% (MICS, 2009a).

\section{Results and Discussions:}

Maternal health situation is one of the most important parts to achieve millennium development goal-4. It is fruitful for the mother and child to keep them under the supervision of a trained person in an emergency situation to reduce delivery complications because a trained person is aware about what to do in what kind of situation. As a trained person we only indicate the doctors, nurses, community clinic health service providers and trained woman in the community who have the ability to help in the delivery situation. Antenatal care, place of delivery and postal cares are also important aspects for maternal health success.

Giving birth rate under the observation of a skilled person was $20.1 \%$ in 2006 and it's increase to $24.4 \%$ in 2009 (MICS, 2009b). From the figure we can see that taking the supervision from the doctor are increasing day by day but keeping themselves under the observation of nurse is reducing.

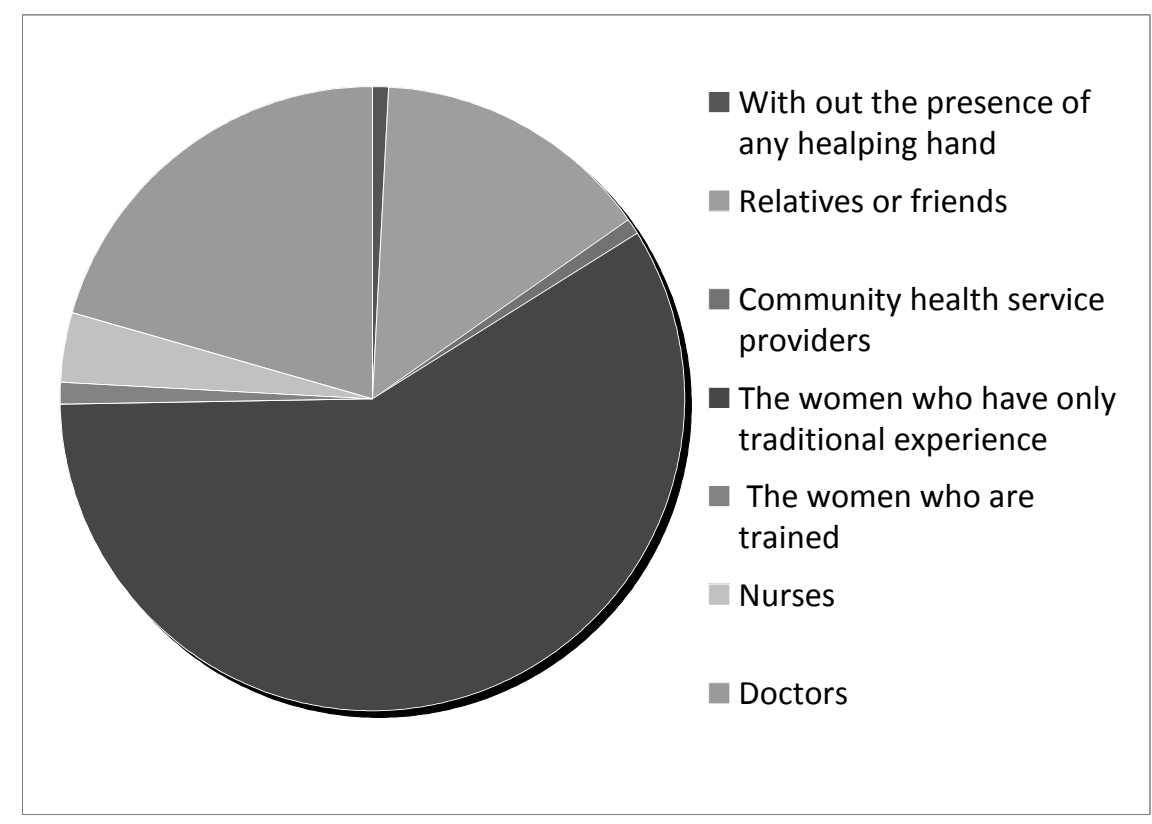

Fig1: The pie chart showing the percentage of assisting in the delivery situation. 


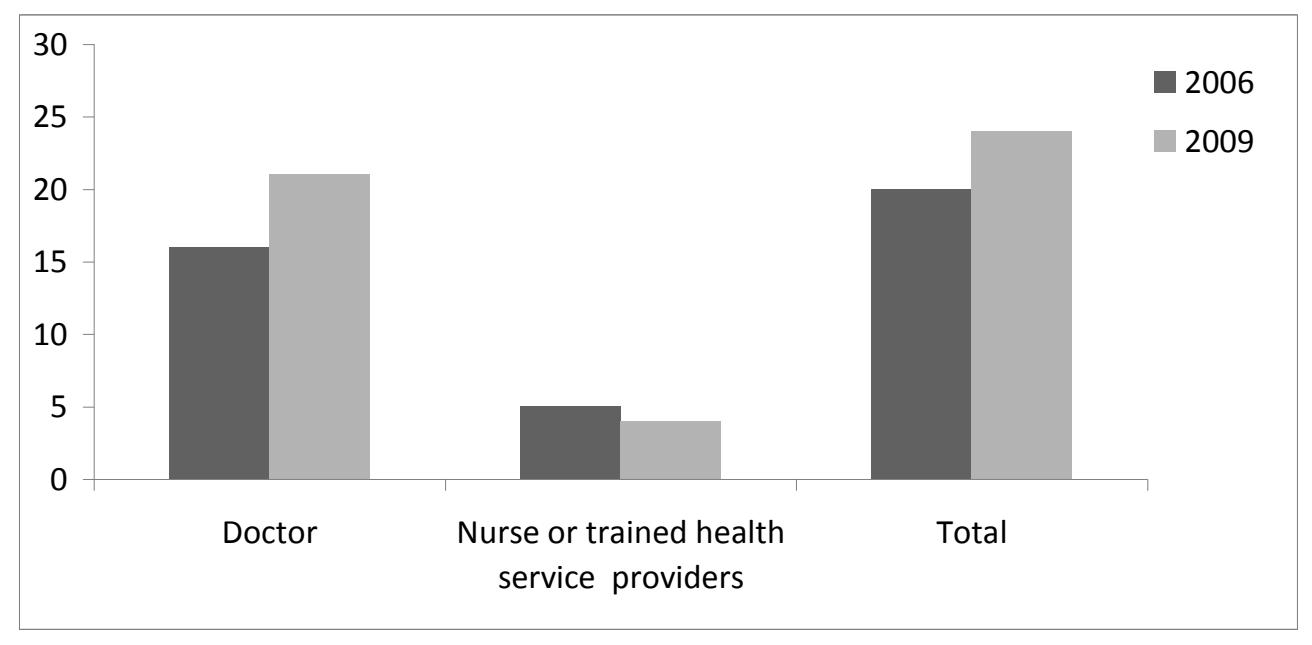

Fig 2: Comparison of assisting by any kind of trained person in delivery situation.

\section{Neonatal health:}

Table 1. The table showing hospital based Neonatal Health status in Bangladesh.

\begin{tabular}{|l|l|l|}
\hline Disease & Total admitted & Total death \\
\hline Neonatal jaundice & $278(30.71 \%)$ & $* 10(6.49 \%)$ \\
\hline Perinatal asphyxia & $199(21.98 \%)$ & $60(38.96 \%)$ \\
\hline Low birth weight & $120(13.25 \%)$ & $32(20.77 \%)$ \\
\hline Septicaemia & $42(9.06 \%)$ & $25(16.23 \%)$ \\
\hline Convulsion & $49(5.45 \%)$ & $4(2.5 \%)$ \\
\hline Very severe pneumonia & $20(2.20 \%)$ & $5(3.24 \%)$ \\
\hline Infant of diabetic mother & $19(2.0 \%)$ & - \\
\hline Haemorrhagic disease & $16(1.7 \%)$ & - \\
\hline Meconium aspiration syndrome & $15(1.65 \%)$ & - \\
\hline Congenital malformation & $15(1.65 \%)$ & - \\
\hline Intrauterine growth retardation & $10(1.105 \%)$ & $10(1.105 \%)$ \\
\hline Others & $82(9.06 \%)$ & $18(11.64 \%)$ \\
\hline
\end{tabular}

*Mortality associated with infection \& low birth weight

\section{Vaccination service:}

Percentage of children under 1 year of age who have received BCG tika (a vaccine against tuberculosis) has been increased from $2 \%$ in 1985 to $99 \%$ in 2009 (Shakeel, 2012a). The coverage of other vaccines has also improved substantially (BRAC, 2009). However poor access to service, low quality of care, and high rate of maternal mortality and poor status of child health still remains as challenges of health sector (Ferdous, 2008).

\section{Child health:}

A child is as sensitive as a mother in the delivery issue. Child mortality rate under 1 year old is about 50 per 1000 in rural area and 42 per 1000 in urban area of Bangladesh. And child mortality rate under 5 years old is 66 per 1000 in rural areas and 53 per 1000 in urban area (MICS, 2009c). 


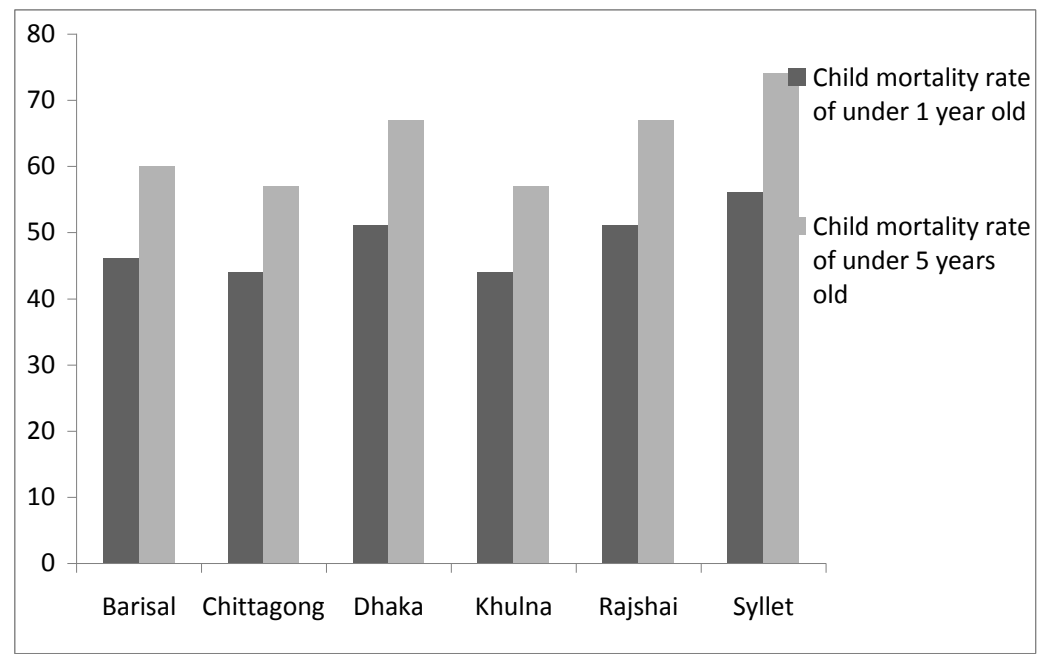

Fig 3 : Division wise child mortality rate per thousand.

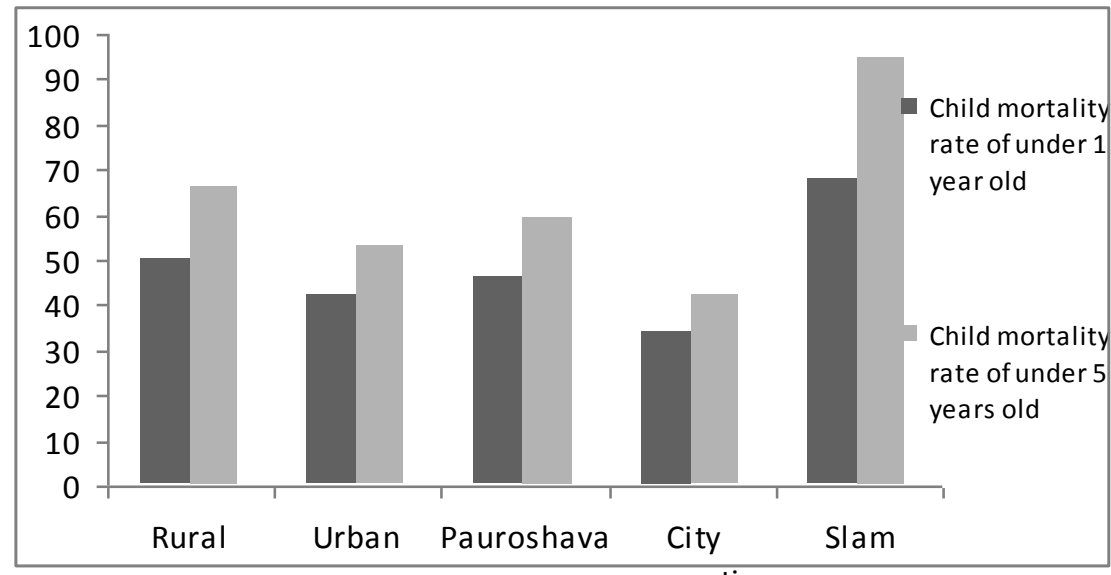

Fig 4 : Area wise child mortality rate per thousand.

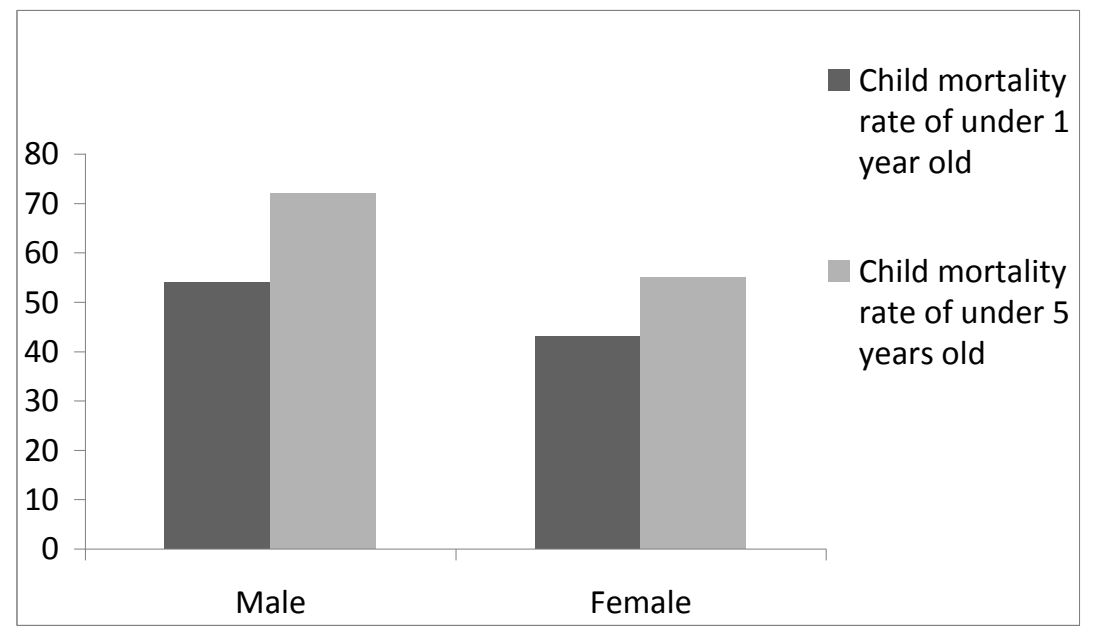

Fig 5 : Gender Wise child mortality rate per thousand. 


\section{Sanitation:}

Improper management of swage and other waste materials are blamable for many kinds of diseases. Joint monitoring program of UNICEF and WHO have given a standard definition of sanitation. Bangladesh national sanitation policy has also given a definition of sanitation. The two definitions are similar but the definition of UNICEF and WHO have some stric $t$ rules about using latrine on the other hand the definition of national sanitation policy has given more emphasis on technical side. In Bangladesh the highest rate of sanitation in Chittagong division about $62 \%$ and lowest rate in let division about $43 \%$. An overview of the tendency of covering by sanitation process in Bangladesh from 1990 to 2015 is given below.

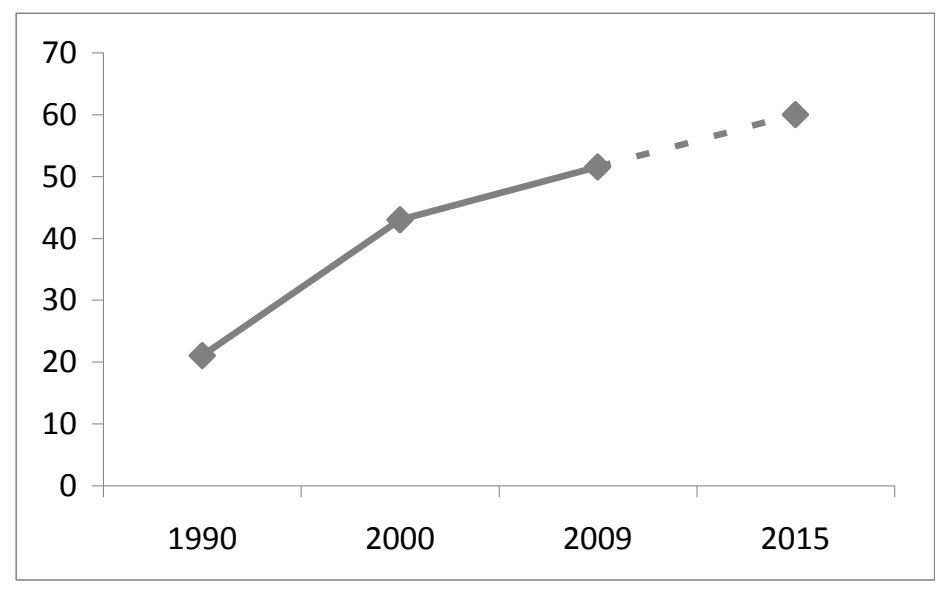

Fig 6 : The inclination of sanitation coverage in Bangladesh.

\section{Safe drinking water:}

Safe drinking water is another issue to ensure sustainable health development. Drinking water may be contaminated in various ways. The water may be contaminated with chemical materials, solid waste and radioactive substances. The unsafe or contaminated drinking water is responsible for various water prone diseases. In the world a single child died per 15 seconds for unsafe drinking water, unhygienic sanitation system and low quality of health service facilities. In all over Bangladesh 97.8\% people use safe drinking water. In urban area this rate is $99.5 \%$ and in rural area this rate is little more than 97.4\% (MICS, 2009d). In district level this rate is lowest in Rangamati $66.5 \%$ and $100 \%$ in Gazipur. In Bangladesh perspective arsenic contamination is one of the major threats to ensure safe drinking water. A figure is given below which will show the awareness about arsenic contamination among the tube-well and underground water users in Bangladesh

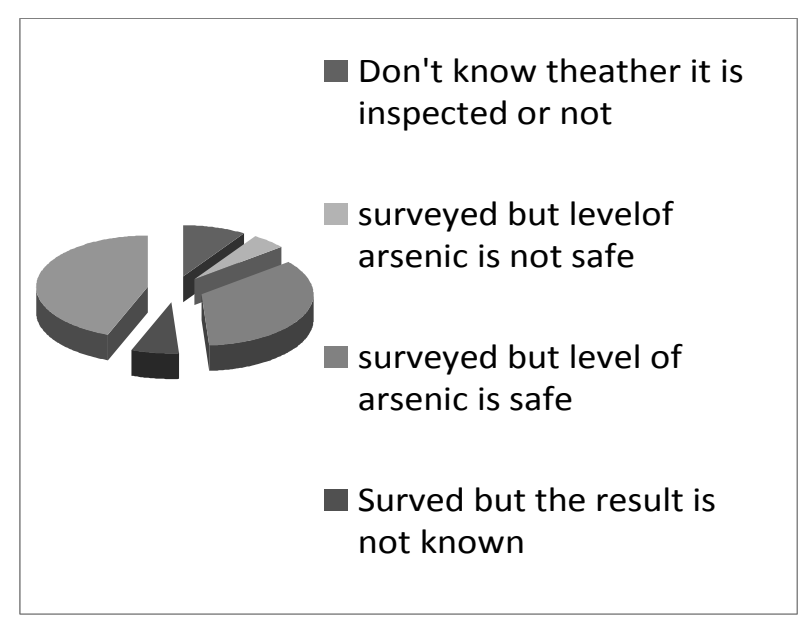

Fig 7 : Awareness about arsenic contamination. 


\section{Dependency ratio of Bangladesh:}

The dependency ratio of a country is also an indicator of the health sector of that country. If the rate of death of new born child is high then the parents will be interested to take more children. Then the dependency rate will increase. The insecure economic stability is also a cause of increasing dependency rate. Girl's education and joining women into work are also responsible for fluctuating the dependency rate.

\section{Use of Tobacco:}

Table 2: Tobacco use data from the latest survey results available to WHO.

\begin{tabular}{|l|l|l|l|l|l|l|}
\cline { 2 - 7 } \multicolumn{2}{c|}{} & Among youth & Among adults & \multicolumn{2}{l|}{} \\
\hline $\begin{array}{l}\text { Smoked } \\
\text { tobacco } \\
\begin{array}{l}\text { Prevalence } \\
(\%)\end{array}\end{array}$ & $\begin{array}{l}\text { Current } \\
\text { tobacco } \\
\text { use }\end{array}$ & $\begin{array}{l}\text { Current } \\
\text { cigarette } \\
\text { use }\end{array}$ & $\begin{array}{l}\text { Current } \\
\text { tobacco } \\
\text { smoking }\end{array}$ & $\begin{array}{l}\text { Daily } \\
\text { tobacco } \\
\text { smoking }\end{array}$ & $\begin{array}{l}\text { Current } \\
\text { cigarette } \\
\text { smoking }\end{array}$ & $\begin{array}{l}\text { Daily } \\
\text { cigarette } \\
\text { smoking }\end{array}$ \\
\hline Male & 9.1 & 2.9 & 54.8 & 53.3 & 37.8 & 36.8 \\
\hline Female & 5.1 & 1.1 & 1.3 & 1.1 & 0.2 & 0.1 \\
\hline Total & 6.9 & 2.0 & 26.2 & 25.4 & 17.7 & 17.2 \\
\hline
\end{tabular}

Source: (Global Tobacco survey, 2007, 2009)

\section{Child labor:}

We have some information in the multiple interact cluster survey 2009 that some children under 6 to 14 years of age but do not go to school and involved in laborious work. In Bangladesh this ratio is $2.3 \%$ among them $2.9 \%$ is boy and $1.7 \%$ is girl.

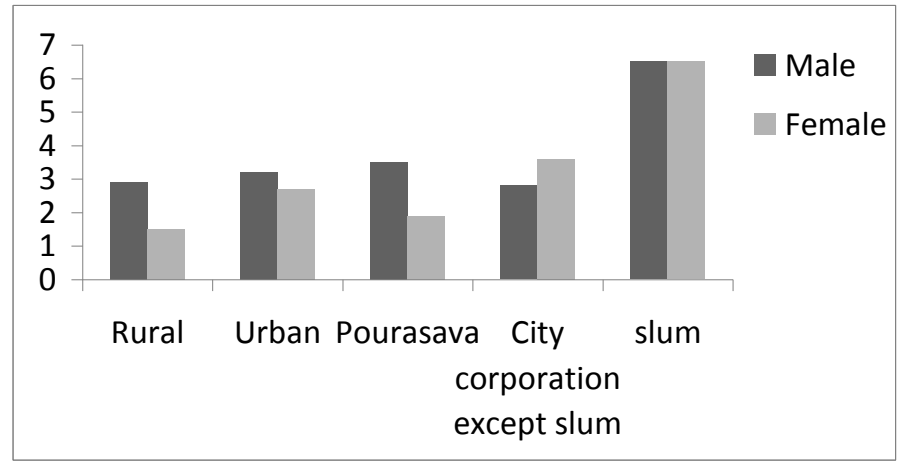

Fig 8 : Gender and area wise involving rate of child labor.

\section{Woman friendly health service:}

Basic human rights by international conference declaration and legal instruments selected that women have the right to have timely, affordable and good quality of health care. The millennium development goals are also highlighting that part. So like other countries the Bangladeshi women also have the rights

\section{Girl's education and joining women into work:}

Girl's education is one of the major issues which have an impact on the health sector of a country. If the girls and women are educated then they will concern about their health, family and environment. It is easier for to have women friendly health service. But it is quite difficult for the distance of the health care. The women in our country are not allowed to move such a far distance place and the religious issue is also a great fact here. They need separate kind of health service in the health care to feel comfortable. The government of Bangladesh and UNICEF has been working tighter for this (BDHS, 2007).

an educated mother to take care of her child than an uneducated mother. If we can involve the women into work then they will be conscious about their family planning and also be aware about their rights and responsibilities. 


\section{Absenteeism of doctors in rural area:}

It is a common phenomenon in Bangladesh that the lack of doctors in rural health complex. Absenteeism of doctors is $40 \%$ in UHC and in the UHFWC's it is as high as 74\% (Chowdhury, 2004). Some health complexes are passing through their daily schedule with only one doctor sometimes without any doctor. The "Social Sector Performance Survey" of primary health and family planning in 2005 also show the similar kind of percentage of absenteeism.

\section{Expensive health service:}

Expensive health service is a common phenomenon in Bangladesh. By this we can also determine the health seeking behavior. When the people fails to afford the high fees of MBBS doctors then they seek assistance of the village doctor, drug sellers or homoeopaths and try to avoid the high consultation fees except the cost of medicines.

\section{The scarcity of the health service providers:}

The distribution of human resources as they needed is the pre-condition for ensuring the health rights of all level people. The state of health in Bangladesh2007 report published by the civil society group says that Bangladesh is still running a straggling shortage of over 60,000 doctors (currently figure 31,000 physicians) and also have a scarcity almost 140,000 nurses. The ratio of doctors and nurse in Bangladesh is very worst. We have only one nurse per three doctors that should be three nurses per one doctor. Scarcity of drugs, poor supply condition and other poor facilities also hamper the activities of the health complex. As a result publicly funded health care system is used by only $25 \%$ of the population (Shakeel, 2012b).

Table 3 : Distribution of Doctors, nurses and dentists per 10,000 people in various Bangladeshi divisions.

\begin{tabular}{|l|l|l|l|l|l|}
\hline Division & Doctors & Nurses & Dentists & All & $\begin{array}{l}\text { Nurse per doctor } \\
\text { ratio }\end{array}$ \\
\hline Dhaka & 10.8 & 2.8 & 0.5 & 14.2 & 0.2 \\
\hline Khulna & 1.3 & 1.9 & 0.05 & 3.3 & 1.4 \\
\hline Rajshahi & 2.1 & 1.1 & 0.0 & 3.2 & 0.5 \\
\hline Sylhet & 2.2 & 0.4 & 0.0 & 3.2 & 0.1 \\
\hline Barisal & 1.7 & 0.9 & 0.3 & 3.08 & 0.5 \\
\hline Chittagong & 4.8 & 3.6 & 0.3 & 8.8 & 0.7 \\
\hline
\end{tabular}

Source: (Ahmed, 2011)

\section{Present health scenario of Bangladesh:}

Table 4 : Present health scenario of Bangladesh

\begin{tabular}{|c|c|}
\hline Population & $163,654,860$ (July 2013 est.) \\
\hline Age structure & $\begin{array}{l}\text { 0-14 years: } 33 \% \text { (male } 27,393,912 / \text { female } 26,601,199 \text { ) } \\
\text { 15-24 years: } 18.8 \% \text { (male } 14,337,930 / \text { female } 16,377,785 \text { ) } \\
\text { 25-54 years: } 37.6 \% \text { (male } 29,091,046 / \text { female } 32,455,670 \text { ) } \\
\text { 55-64 years: } 5.7 \% \text { (male } 4,775,062 / \text { female } 4,625,192 \text { ) } \\
\text { 65 years and over: } 4.9 \% \text { (male } 3,918,341 / \text { female } 4,078,723 \text { ) (2013 est.) }\end{array}$ \\
\hline Dependency ratios & $\begin{array}{l}\text { total dependency ratio: } 53.3 \% \\
\text { youth dependency ratio: } 46 \% \\
\text { elderly dependency ratio: } 7.3 \% \\
\text { potential support ratio: } 13.6(2013)\end{array}$ \\
\hline Median age & $\begin{array}{l}\text { total: } 23.9 \text { years } \\
\text { male: } 23.4 \text { years } \\
\text { female: } 24.4 \text { years }(2013 \text { est.) }\end{array}$ \\
\hline Population growth rate & $1.59 \%$ (2013 est.) \\
\hline Birth rate & 22.07 births/1,000 population (2013 est.) \\
\hline Death rate & 5.67 deaths/1,000 population (2013 est.) \\
\hline Net migration rate & -0.52 migrant(s)/1,000 population (2013 est.) \\
\hline Urbanization & urban population: $28.4 \%$ of total population (2011) \\
\hline
\end{tabular}




\begin{tabular}{|c|c|}
\hline & rate of urbanization: $2.96 \%$ annual rate of change (2010-15 est.) \\
\hline Major cities - population & $\begin{array}{l}\text { DHAKA (capital) } 15.391 \text { million; Chittagong } 4.816 \text { million; Khulna } 1.636 \text { million; } \\
\text { Rajshahi } 853,000 \text { (2011) }\end{array}$ \\
\hline Sex ratio & $\begin{array}{l}\text { at birth: } 1.04 \text { male }(\mathrm{s}) / \text { female } \\
\text { 0-14 years: } 1.03 \text { male }(\mathrm{s}) / \text { female } \\
\text { 15-24 years: } 0.87 \text { male }(\mathrm{s}) / \text { female } \\
\mathbf{2 5 - 5 4} \text { years: } 0.9 \text { male }(\mathrm{s}) / \text { female } \\
\text { 55-64 years: } 1.05 \text { male }(\mathrm{s}) / \text { female } \\
\text { 65 years and over: } 0.96 \mathrm{male}(\mathrm{s}) / \text { female } \\
\text { total population: } 0.95 \text { male }(\mathrm{s}) / \text { female }(2013 \text { est.) }\end{array}$ \\
\hline Mother's mean age at first birth & 18.1 (2007 est.) \\
\hline Infant mortality rate & $\begin{array}{l}\text { total: } 47.3 \text { deaths } / 1,000 \text { live births } \\
\text { male: } 49.79 \text { deaths } / 1,000 \text { live births } \\
\text { female: } 44.71 \text { deaths } / 1,000 \text { live births ( } 2013 \text { est.) }\end{array}$ \\
\hline Life expectancy at birth & $\begin{array}{l}\text { total population: } 70.36 \text { years } \\
\text { male: } 68.48 \text { years } \\
\text { female: } 72.31 \text { years }(2013 \text { est.) }\end{array}$ \\
\hline Total fertility rate & 2.5 children born/woman (2013 est.) \\
\hline Contraceptive prevalence rate & $61.2 \%(2011 / 12)$ \\
\hline HIV/AIDS - adult prevalence rate & less than $0.1 \%$ (2009 est.) \\
\hline $\begin{array}{l}\text { HIV/AIDS - people living with } \\
\text { HIV/AIDS }\end{array}$ & 6,300 (2009 est.) \\
\hline HIV/AIDS - deaths & fewer than 200 (2009 est.) \\
\hline Drinking water source & $\begin{array}{l}\text { improved: } \\
\text { urban: } 85 \% \text { of population } \\
\text { rural: } 80 \% \text { of population } \\
\text { total: } 81 \% \text { of population } \\
\text { unimproved: } \\
\text { urban: } 15 \% \text { of population } \\
\text { rural: } 20 \% \text { of population } \\
\text { total: } 19 \% \text { of population }(2010 \text { est.) }\end{array}$ \\
\hline Sanitation facility access & $\begin{array}{l}\text { improved: } \\
\text { urban: } 57 \% \text { of population } \\
\text { rural: } 55 \% \text { of population } \\
\text { total: } 56 \% \text { of population } \\
\text { unimproved: } \\
\text { urban: } 43 \% \text { of population } \\
\text { rural: } 45 \% \text { of population } \\
\text { total: } 44 \% \text { of population }(2010 \text { est.) }\end{array}$ \\
\hline Major infectious diseases & $\begin{array}{l}\text { degree of risk: high } \\
\text { food or waterborne diseases: bacterial and protozoal diarrhea, hepatitis A and E, } \\
\text { and typhoid fever } \\
\text { vectorborne diseases: dengue fever and malaria are high risks in some locations } \\
\text { water contact disease: leptospirosis } \\
\text { animal contact disease: rabies } \\
\text { note: highly pathogenic H5N1 avian influenza has been identified in this country; it } \\
\text { poses a negligible risk with extremely rare cases possible among US citizens who } \\
\text { have close contact with birds (2013) }\end{array}$ \\
\hline Nationality & $\begin{array}{l}\text { noun: Bangladeshi(s) } \\
\text { adjective: Bangladeshi }\end{array}$ \\
\hline Ethnic groups & Bengali $98 \%$, other $2 \%$ (includes tribal groups, non-Bengali Muslims) (1998) \\
\hline Religions & Muslim $89.5 \%$, Hindu $9.6 \%$, other $0.9 \%(2004)$ \\
\hline Languages & Bangla (official, also known as Bengali), English \\
\hline Literacy & $\begin{array}{l}\text { definition: age } 15 \text { and over can read and write } \\
\text { total population: } 57.7 \% \\
\text { male: } 62 \% \\
\text { female: } 53.4 \% \text { (2011 est.) }\end{array}$ \\
\hline $\begin{array}{l}\text { School life expectancy (primary to } \\
\text { tertiary education) }\end{array}$ & $\begin{array}{l}\text { total: } 8 \text { years } \\
\text { male: } 8 \text { years } \\
\text { female: } 8 \text { years }(2007)\end{array}$ \\
\hline Child labor - children ages 5-14 & total number: $4,485,497$ \\
\hline
\end{tabular}




\begin{tabular}{|l|l|}
\hline & percentage: $13 \%(2006$ est.) \\
\hline Education expenditures & $2.2 \%$ of GDP $(2009)$ \\
\hline Maternal mortality rate & 240 deaths/100,000 live births $(2010)$ \\
\hline $\begin{array}{l}\text { Children under the age of 5 years } \\
\text { underweight }\end{array}$ & $41.3 \%(2007)$ \\
\hline Health expenditures & $3.7 \%$ of GDP $(2011)$ \\
\hline Physicians density & 0.356 physicians/1,000 population $(2011)$ \\
\hline Hospital bed density & 0.6 beds/1,000 population $(2011)$ \\
\hline Obesity - adult prevalence rate & $1.1 \%(2008)$ \\
\hline
\end{tabular}

\section{The scenario of rural community health problem:}

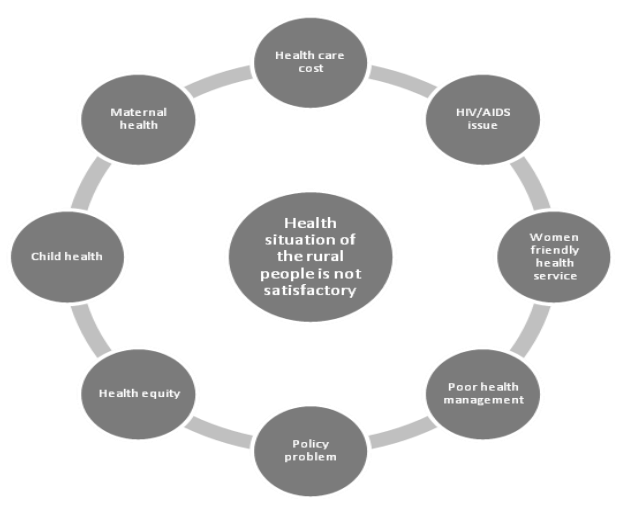

Fig 9 : Gender and area wise involving rate of child labor.

\section{Impact of politics in health policy making:}

Like other developing country the lifetime of a public policy in Bangladesh depends on the change of political power and health policy is no exception. Visions and directions of all health policies got changed with the change of the ruling government. Many arguments took in favor of policy reversal by the policy actors but the decision remains absolutely political.

\section{National health policies evolutions in Bangladesh:}

Though Bangladesh has one of the strongest networks among the developing countries to deliver health service to all level people, still the qualities of services are not up to mark. The health system of Bangladesh is the outcome of many policy shifts and change. During the independent the country was urban based and the health system was limited in terms of medical facilities and services. As the time passes the country developed urban areas and the population is getting large and the policy is needed to be changed for the developed and large population to fulfill their needs. A common scenario of Bangladesh health policy from 1970 to 2008 is given here.

\begin{tabular}{|l|l|}
\hline Time & Main Theme/Initiatives /Objectives. \\
\hline $1970-71$ & Urban and elite-biased curative health system. \\
\hline $\begin{array}{l}\text { first Five Year Plan } \\
(1973-78)\end{array}$ & $\begin{array}{l}\text { The strategy of establishing health infrastructures ( Thana and Union } \\
\text { Level) along with capacity building of health professionals. }\end{array}$ \\
\hline $\begin{array}{l}\text { First population policy } \\
1976\end{array}$ & $\begin{array}{l}\text { To provide comprehensive health and family planning services } \\
\text { Primarily through service centre i.e. clinics and female field workers, } \\
\text { with strong emphasis on doorstep services to rural women. }\end{array}$ \\
\hline $\begin{array}{l}\text { Two Year Plan } \\
(1978-80)\end{array}$ & Reflection of First Population Policy. \\
\hline $\begin{array}{l}\text { Second Five Year Plan } \\
(1980-85) .\end{array}$ & Health for All within 2000 and Primary health Care. \\
\hline Third Five Year Plan & Emphasized on Mater Child Health under Primary Health Care. \\
\hline
\end{tabular}




\begin{tabular}{|l|l|}
\hline $\begin{array}{l}\text { Fourth Five Year Plan } \\
(1980-85) .\end{array}$ & Emphasized on Mater Child Health under Primary Health Care. \\
\hline $\begin{array}{l}\text { Fifth Five Year Plan } \\
(1997-2002)\end{array}$ & $\begin{array}{l}\text { Essential Service Packages of Health Services and Unification of } \\
\text { Health and Family. }\end{array}$ \\
\hline $\begin{array}{l}\text { Health and Population } \\
\text { Sector Program(HPSP) } \\
(1998-2003)\end{array}$ & $\begin{array}{l}\text { Sector Wide Approach in Health Sector of Bangladesh. Efficiency and } \\
\text { cost-effectiveness by advocating certain institutional and governance } \\
\text { reforms. }\end{array}$ \\
\hline $\begin{array}{l}\text { National Health Policy } \\
2000\end{array}$ & $\begin{array}{l}\text { All the basic services under Essential service package are being } \\
\text { delivered through hone-stop service centers at the Upazil ( UHC), } \\
\text { Union (UHFWC) and partially at the village. }\end{array}$ \\
\hline $\begin{array}{l}\text { Heath Policy Update } \\
2008\end{array}$ & $\begin{array}{l}\text { Update the health policy focusing on the poor and the disadvantaged } \\
\text { keeping the continuity of certain elements of the existing health policy } \\
\text { with some additions as main feature. }\end{array}$ \\
\hline
\end{tabular}
Source: (Perry, 2000; Osman, 200; BHW, 2010)

\section{Conclusions}

The last three decades are more impressive in development stage condition. The utilizations of health care facilities and services have sharply increased due to awareness development, the upliftment of socioeconomic capacity of the people over the years with the enhancement and improvement of systemic health management. The progress of health care system has worked much, the government should support funding and logistic to continue and promote the enhancement of overall health care system in Bangladesh.

\section{References}

Ahmed, 2011 9:3doli: 10.1186/1478-4491-9-3and Associates, and Macro International.2009.

BBS and UNICEF, 2009a. Bangladesh Multiple Indicator Cluster Survey 2009, Final Report, Dhaka, Bangladesh: BBS and UNICEF

BBS and UNICEF, 2009b. Bangladesh Multiple Indicator Cluster Survey 2009, Final Report, Dhaka, Bangladesh: BBS and UNICEF

BBS and UNICEF, 2009c. Bangladesh Multiple Indicator Cluster Survey 2009, Final Report, Dhaka, Bangladesh: BBS and UNICEF

BBS and UNICEF, 2009d. Bangladesh Multiple Indicator Cluster Survey 2009, Final Report, Dhaka, Bangladesh: BBS and UNICEF

BDHS, 2007. National Institute of Population Research and Training (NIPORT), Mitra

BHW (2010). The Sate of Health in Bangladesh 2007 : Health Workforcein Bangladesh ,Bangladesh Health Watch ( BHW), BRAC University School of Public Health, Dhaka
BRAC 2009. Available at: http://sph.bracu.ac.bd/publications/reports/ monograph/Monograph\%20Series\%2011.pdf. Accessed on: May7, 2012

Chaudhury, N. and Hammer. J.S. 2004. "Ghost Doctors: Absenteeismin Rural BangladeshiHealth Facilities." World Bank Economic Review $18(3)$

Global Adult Tobacco Survey, 2009; WHO Report on the Global Tobacco Epidemic, 2013. National, ages $15+$

Global Youth Tobacco Survey, 2007; WHO Report on the Global Tobacco Epidemic, 2013, National, ages 13-15 Non-Communicable Disease Risk Factor Survey, 2010; National, ages 25+

Ferdous, A. 2004. Policy Makingin Bangladesh: A Study of the Health Policy Process. Bangladesh: A H Development Publishing House, Dhaka.

Perry, H.B. 2000. Health for All in Bangladesh. Dhaka: University Press Population Research and Training, Mitra and Associates, and Macro International.

Islam, M.N. 2000. Situation of Neonatal health in Bangladesh, , Orion group, Vol: 6

Shakeel, A. I. M. 2012a. Health system and Policy research, IMEDPub journals, Vol:1, No:1:1, page no:2

Shakeel, A.I. M. 2012b. Health system and Policy research, IMEDPub journals, 1(1:1) page no:2

Survey, 2007. Dhaka, Bangladesh and Calverton, Maryland, USA: National Institute of WHO and UNISEF joined monitoring program for water supply and sanitation 2008 